\title{
Sampling planktonic salmon lice in Norwegian fjords
}

\author{
Jofrid Skarðhamar ${ }^{1, *}$, Margrethe Nilsen Fagerli' ${ }^{2}$, Marit Reigstad ${ }^{2}$, \\ Anne Dagrun Sandvik ${ }^{1}$, Pål Arne Bjørn ${ }^{1}$ \\ ${ }^{1}$ Institute of Marine Research, PO Box 1870 Nordnes, 5817 Bergen, Norway \\ ${ }^{2}$ UiT The Arctic University of Norway, PO Box 6050 Langnes, 9037 Tromsø, Norway
}

\begin{abstract}
Risk of mortality of wild salmon caused by salmon lice is used as an index for managing aquaculture production in Norway and is based on monitoring of lice attached to wild salmonids and modelled concentrations of lice larvae in fjords. Direct sampling of lice from Norwegian waters to determine concentrations has never been published scientifically and has been considered non-feasible for monitoring purposes. Here we tested 4 different methods for sampling planktonic salmon lice copepodids. Salmon lice were found using all 4 methods with highly variable concentrations related to volume of filtered water with the different methods and patchy and variable distribution of lice within the fjords. Comparison between modelled and sampled lice concentrations showed variability within the same range and aspects of patchiness, and that the modelled concentrations were mostly lower than observed. We conclude that planktonic salmon lice can be sampled in Norwegian fjords with standard zooplankton sampling methods. Development of monitoring programmes of planktonic lice is possible but will demand a large amount of resources if implemented along the entire coast, because extensive sampling programmes and manpower for analysing samples are required to be able to capture the high spatiotemporal variability and patchy distribution of salmon lice. This calls for further development and use of modelling as a primary tool for national monitoring and management purposes. For further investigations of the effects of infestation pressure on wild salmonids, sampling combined with numerical modelling can provide valuable information.
\end{abstract}

KEY WORDS: Lepeophtheirus salmonis - Copepodids - Sea lice $\cdot$ Aquaculture $\cdot$ Concentration · Numerical modeling $\cdot$ Sampling methods

\section{INTRODUCTION}

In many coastal areas and fjords with intensive salmon farming activity, salmon lice Lepeophtheirus salmonis (Krøyer, 1837) cause welfare issues for farmed fish, significant economic losses for the aquaculture industry in general and threats to wild salmonid populations (Ashley 2007, Costello 2009, Taranger et al. 2015, Forseth et al. 2017).

In Norway, there has been an increasing concern for the preservation of wild salmonids, especially Atlantic salmon Salmo salar. In the last decade, this has led to restricted increase of aquaculture production as

${ }^{*}$ Corresponding author: jofrid.skardhamar@hi.no well as limited granting of new production licences because the impact of the aquaculture industry, especially by salmon lice and escaped farmed salmon, has been considered a severe threat for wild salmonids (Taranger et al. 2015, Forseth et al. 2017). In a white paper (Anonymous 2015), the Norwegian government therefore suggested a new management solution for the aquaculture industry, the traffic light system, which was ratified $\mathbf{1}$ in January 2017. In this management system, the effects of salmon lice on wild salmonid populations are the basis for regulatory framework governing the growth rate of farmed salmon production in defined production zones along the entire Nor-

(C) The authors 2019. Open Access under Creative Commons by Attribution Licence. Use, distribution and reproduction are unrestricted. Authors and original publication must be credited. 
wegian coastline. Based on hydrodynamic model estimates of dispersion and abundance of planktonic lice stages along the Norwegian coast (Asplin et al. 2014, Johnsen et al. 2014, 2016, Samsing et al. 2016, Sandvik et al. 2016a, Myksvoll et al. 2018, Skarðhamar et al. 2018), combined with field observations of salmon lice prevalence and intensity on wild salmonids captured in the national monitoring program (National salmon lice observation programme [NALO]) (Grefsrud et al. 2018), the first regulatory assessment $\underline{2}$ was implemented in October 2017. Norway is the only nation with an advanced salmon lice modelling system: a high-resolution ocean model for the whole Norwegian coast, coupled with a state-of-theart salmon lice drift model including all known parameterisations of salmon lice development and behaviour and with realistic input data based on weekly counts of lice reported to the authorities from all aquaculture farms. The NALO program provides observational data of salmon lice attached to wild-caught salmonids (nets, traps and trawl) and to hatcheryreared post smolts kept in sentinel cages as a proxy for salmon lice infestation pressure in fjords and coastal water. This is logistically demanding, expensive and hampered by methodological difficulties and uncertainty (Thorstad et al. 2015, Vollset et al. 2018). Wild sea trout post smolts, for example, leave their marine feeding areas and return prematurely to freshwater when exposed to intensive salmon lice infestation pressure (Birkeland 1996, Serra-Llinares et al. 2018). Direct sampling of salmon lice in seawater has not been included in NALO. Sampling of salmon lice is methodically more demanding than for other and more abundant plankton because the abundance of salmon lice is relatively low compared to other holoplankton species of similar size range. For example, Calanus finmarchicus and Metridia spp. have been found in concentrations of 10000 to 100000 ind. $\mathrm{m}^{-3}$ on the Norwegian coast (Halvorsen et al. 1999), while published concentrations of salmon lice are typically less than 1 ind. $\mathrm{m}^{-3}$ in Scottish and Faroese open waters (Penston et al. 2004, 2011, á Norði et al. 2015, 2016, Salama et al. 2017).

Observational data on planktonic salmon lice can potentially provide valuable additional information to

\footnotetext{
1 https://www.regjeringen.no/no/dokumenter/forskrift-omproduksjonsomrader-for-akvakultur-av-matfisk-i-sjo-avlaks-orret-og-regnbueorret-produksjonsomradeforskriften/ id2527418/

2https://www.regjeringen.no/no/aktuelt/regjeringen-skrurpa-trafikklyset/id2577032/
}

assess infestation pressure on wild salmonids, evaluate model estimates of lice concentrations, and develop a more functional relationship in time and space between modelled concentrations of planktonic lice to the observations of lice attached to salmonid fish. The hydrodynamic dispersion model for salmon lice used for the new management in Norway is unique in a global context because real weekly numbers for salmon lice are reported and available from all farms along the coast. This dataset provides realistic input data to the model of lice larvae to be dispersed with the high-resolution modelled currents. We therefore expect the model to estimate realistic concentrations of lice in the water masses, although this has not yet been proven directly as observational data do not exist. However, the modelled lice levels have been shown to be well correlated with observed infestation pressure from NALO (Sandvik et al. 2016a, Myksvoll et al. 2018).

A few attempts at lice sampling with horizontal tows have previously been made in Norway without success (Asplin et al. 2011), probably due to patchy distributions and low concentrations of lice and waves disturbing sampling near the surface. Sampling of planktonic salmon lice has therefore not been considered feasible, for management and monitoring purposes. We therefore address the following research questions: (1) Is it possible to sample and identify pelagic salmon lice copepodids in Norwegian fjords and coastal waters, including first estimates of lice concentrations and vertical distribution? (2) If so, can sampling of planktonic salmon lice be included in monitoring programs? (3) Can sampled abundance of planktonic salmon lice be used for evaluation of hydrodynamic lice dispersion model systems used as tools for management systems?

To address these questions, we sampled pelagic lice with a suite of different methods, assessed the efficiency of these methods, and compared the sampled lice concentrations with results from a high-resolution hydrodynamic lice dispersion model.

\section{MATERIALS AND METHODS}

\subsection{Study areas}

Sampling was conducted in 2 Norwegian fjords: a pilot study in Hardangerfjorden on the west coast $\left(\sim 59^{\circ} \mathrm{N}\right)$ in 2014 and 3 cruises in Altafjorden in northern Norway $\left(\sim 70^{\circ} \mathrm{N}\right.$, Fig. 1) in 2015. Both fjords are topographically complex systems with several arms, bays and narrows. In Hardanger- 


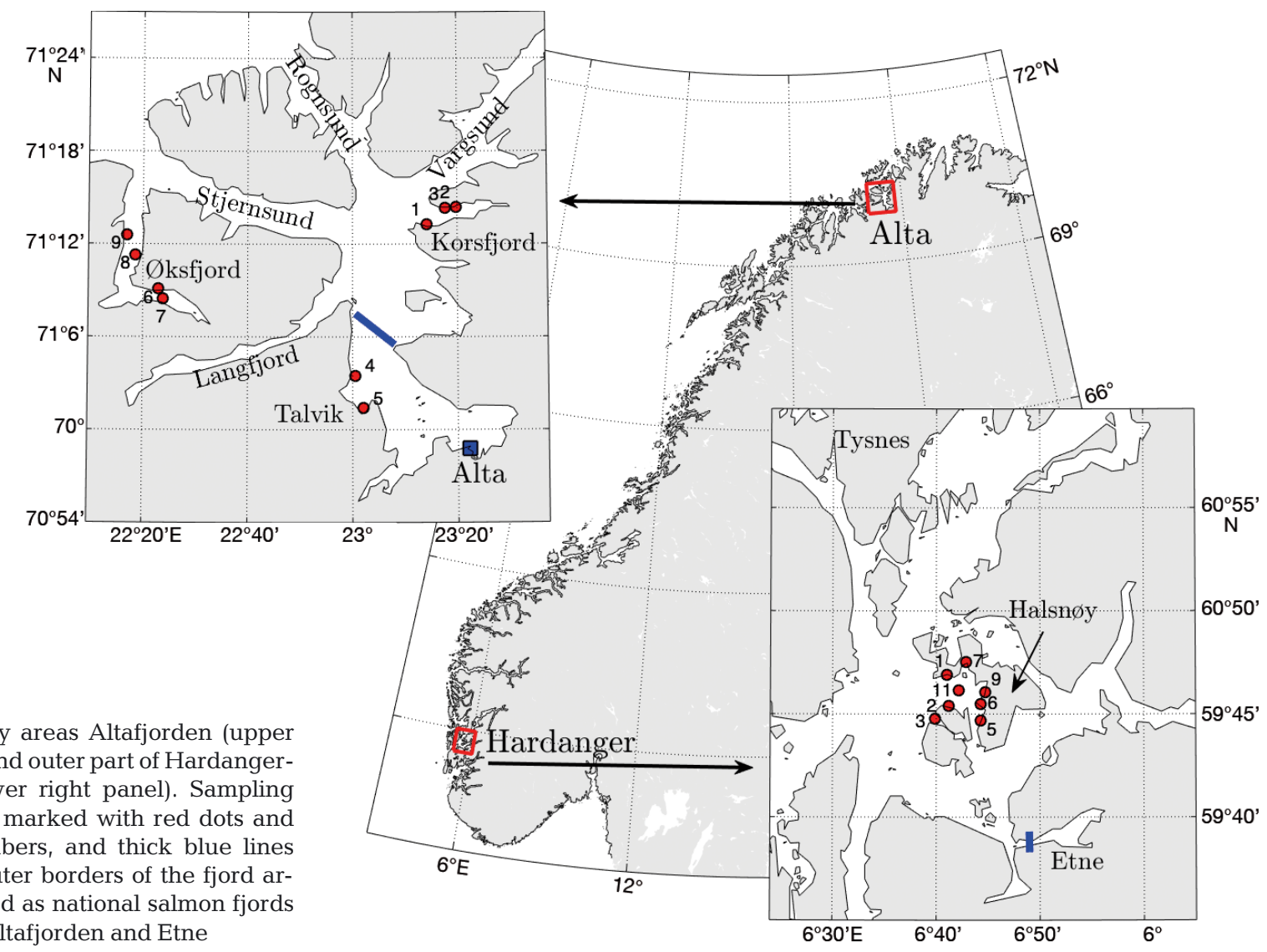

Fig. 1. Study areas Altafjorden (upper left panel) and outer part of Hardangerfjorden (lower right panel). Sampling stations are marked with red dots and station numbers, and thick blue lines show the outer borders of the fjord areas protected as national salmon fjords in Altafjorden and Etne

fjorden, the period of high surface layer temperatures in summer typically lasts 3 mo (July-September, $14-17^{\circ} \mathrm{C}$ at $10 \mathrm{~m}$ depth, Asplin et al. 2014), while in Altafjorden the highest monthly mean temperature is $10.5^{\circ} \mathrm{C}$ in the upper $5 \mathrm{~m}$ in August (Eilertsen \& Skarðhamar 2006, Mankettikkara 2013). Both fjords host wild stocks of salmonids (Atlantic salmon Salmo salar, sea trout $S$. trutta and migratory Arctic char Salvelinus alpinus), and they are also important for the aquaculture industry, with $>20$ farm locations in Altafjorden and $>50$ in Hardangerfjorden (see www.barentswatch.no). The inner part of Altafjorden and the fjord arm Etnefjorden in Hardangerfjorden are protected as national salmon fjords (Fig. 1; Sønvisen 2003, Aasetre \& Vik 2013), where no aquaculture farms are allowed. Both fjords receive large volumes of freshwater from rivers. In Altafjorden, the discharge is dominated by the large river Altaelva, from which the discharge can exceed $1000 \mathrm{~m}^{3} \mathrm{~s}^{-1}$ in May and June (Røhr et al. 2003), producing a typically 5 to $10 \mathrm{~m}$ thick brackish water layer in the main part of the fjord in summer (Eilertsen \& Skarðhamar 2006, Mankettikkara 2013, Skarðhamar et al. 2018). Hardangerfjorden is af- fected by several rivers, and the total discharge estimated from 70 rivers (Petterson 2008) is typically $1000 \mathrm{~m}^{3} \mathrm{~s}^{-1}$ in summer, often exceeding $1500 \mathrm{~m}^{3} \mathrm{~s}^{-1}$ in autumn and winter, affecting the stratification and water exchange (Asplin et al. 2014).

\subsection{Sampling approach}

Low concentrations combined with patchy distributions near the surface make it challenging to collect planktonic stages of salmon lice. In Hardangerfjorden, salmon lice were sampled on 4-6 September 2014, west of Halsnøy (Fig. 1). The salmon lice abundance was expected to be high in this area based on reports from nearby farms and operational lice dispersion modelling (http://lakselus.no). In Altafjorden, salmon lice sampling took place on 22-24 August, 18-20 September and 8-10 October 2015, in the 2 fjord arms Korsfjorden and Øksfjorden and in Talvik within the protected part of the fjord (Fig. 1).

Four different sampling methods were used (Table 1). The vertical distribution of lice was investigated by repeated sampling with Go-Flo water bot- 
Table 1. Sampling stations and methods

\begin{tabular}{|lccccc|}
\hline Date & Stn & Method & $\begin{array}{c}\text { Depth } \\
(\mathrm{m})\end{array}$ & $\begin{array}{c}\text { Mesh size } \\
(\mu \mathrm{m})\end{array}$ & $\begin{array}{c}\text { Volume } \\
(\mathrm{l})\end{array}$ \\
\hline Hardangerfjorden & & & & & \\
4-6 Sep 2014 & $1,2,6,7,11$ & Go-Flo & $3,5,10$ & 90 & 100 \\
& $1,2,6,7,11$ & Horizontal tow & 4 & 90 & 25000 \\
& $1,2,6,7,11$ & Vertical haul & $0-10$ & 90 & 2500 \\
& $3,5,9$ & Go-Flo & 3 & 90 & 100 \\
& $3,5,9$ & Vertical haul & $10-0$ & 90 & 2500 \\
Altafjorden & \multicolumn{7}{c}{} & & & & \\
22-24 Aug 2015 & $1-9$ & Go-Flo & 3 & 180 & 150 \\
& $1-9$ & Pump & 1,3 & 180 & 1000 \\
18-20 Sep 2015 & $1-9$ & Vertical haul & $10-0$ & 180 & 2500 \\
8-10 Oct 2015 & $1-9$ & Pump & 1,3 & 90 & 1000 \\
& & Pump & 1,3 & 90 & 1000 \\
\hline
\end{tabular}

tles at selected depths (sampling volume 100-150 l) and also by pumping large water volumes (1000 l) with a provisional bilge pump ('pump' in tables) from specific depths and sieved through a plankton net (WP2). The vertically integrated abundance of lice was sampled with a WP2 net, which is a ring net with an opening of $0.25 \mathrm{~m}^{2}$ and a small mesh width. We used 90 or $180 \mu \mathrm{m}$ (tested to assure that no lice were lost with $180 \mu \mathrm{m})$, the latter resulting in less clogging. The net was pulled vertically at a speed of $0.5 \mathrm{~m} \mathrm{~s}^{-1}$ to ensure efficient filtration. The lower end of the net was closed off at one end, with a cylinder collecting the plankton. Vertical hauls with the WP2 net through the upper $10 \mathrm{~m}$ gave a sampling volume of 2500 l. The WP2 net was also towed horizontally at $4 \mathrm{~m}$ depth over a distance of $100 \mathrm{~m}$ at a speed of $0.4 \mathrm{~m} \mathrm{~s}^{-1}$, obtaining a sampling volume of $25000 \mathrm{l}$. The depth of $4 \mathrm{~m}$ was the shallowest depth possible to sample due to waves. All samples were concentrated using a sieve (90 or $180 \mu \mathrm{m}$ ) and preserved with a formaldehyde mix to $4 \%$ final concentration (formaldehyde buffered with hexamethylenetetramine and added propandiol, $20 \%$ ).

Vertical profiles of temperature and salinity were recorded at all stations using a CTD (SAIV SD204) lowered manually and slowly $\left(<0.5 \mathrm{~m} \mathrm{~s}^{-1}\right)$ to $10 \mathrm{~m}$ depth in Hardanger and 20 to $50 \mathrm{~m}$ depth in Alta, with sampling frequency $1 \mathrm{~s}^{-1}$, giving 2 to 3 measurements per meter. The upper bound of accuracy of the SD204 is $\pm 0.01^{\circ} \mathrm{C}$ for temperature and \pm 0.02 for salinity, which is sufficient for fjord waters, where variations in temperature and salinity are typically large, i.e. $\approx 1$ or larger on the unit scale. The CTD measurements shown in Fig. 2 were binned to $0.5 \mathrm{~m}$ intervals before plotting.

\subsection{Identification}

The preserved samples were analysed using a stereo microscope (Leica MZ16, 40-100× magnification). Each sample had to be analysed entirely (no subsamples), and all sea lice copepodids were counted and identified using taxonomic descriptions by Schram (2004) and Danielsen (2013). In total, for all cruises, 139 sea lice copepodids were identified.

Formaldehyde caused a loss of the characteristic pigmentations in the animals, making it difficult to distinguish Lepeophtheirus salmonis from Caligus elongatus, another sea lice species occurring in northern Norway. Therefore, the sampled free-living copepodids were identified only to family, Caligidae (sea lice). To obtain species identification based on pigmentation, fresh unpreserved samples or ethanol-preserved samples analysed within a few days from ethanol immersion have to be used (Schram 2004). In the present study, this approach for species identification was not possible due to the long travel times between sampling area and feasible laboratory facilities and the time needed to analyse the full field-based plankton samples. Lice naupliar stages are similarly challenging to identify to species and also to tell apart from nauplii of other copepod species in formaldehyde-preserved samples, as use of pigmentation colour and distribution is considered a key factor (Schram 2004). Naupliar stages were therefore not identified in the present study. To obtain a measure of the size distribution of the sampled copepodids, the prosome length of all sea lice copepods was measured. In addition, the total lengths of 15 individuals were measured to establish a ratio between the 2 measurements to facilitate comparison with different traditions in literature, referring to total length of sea lice, and prosome length of planktonic copepods (Schram 2004, Skjoldal et al. 2013). The average ratio (prosome length/total length $\pm \mathrm{SD}$ ) in the present study was $0.65 \pm 0.03$.

\subsection{Numerical model}

Dispersion and abundance of planktonic salmon lice copepodids were modelled with a numerical modelling system developed for the Norwegian coast (Albretsen et al. 2011, Asplin et al. 2014, Johnsen et al. 2014, 2016, Sandvik et al. 2016a, Myksvoll et al. 
a
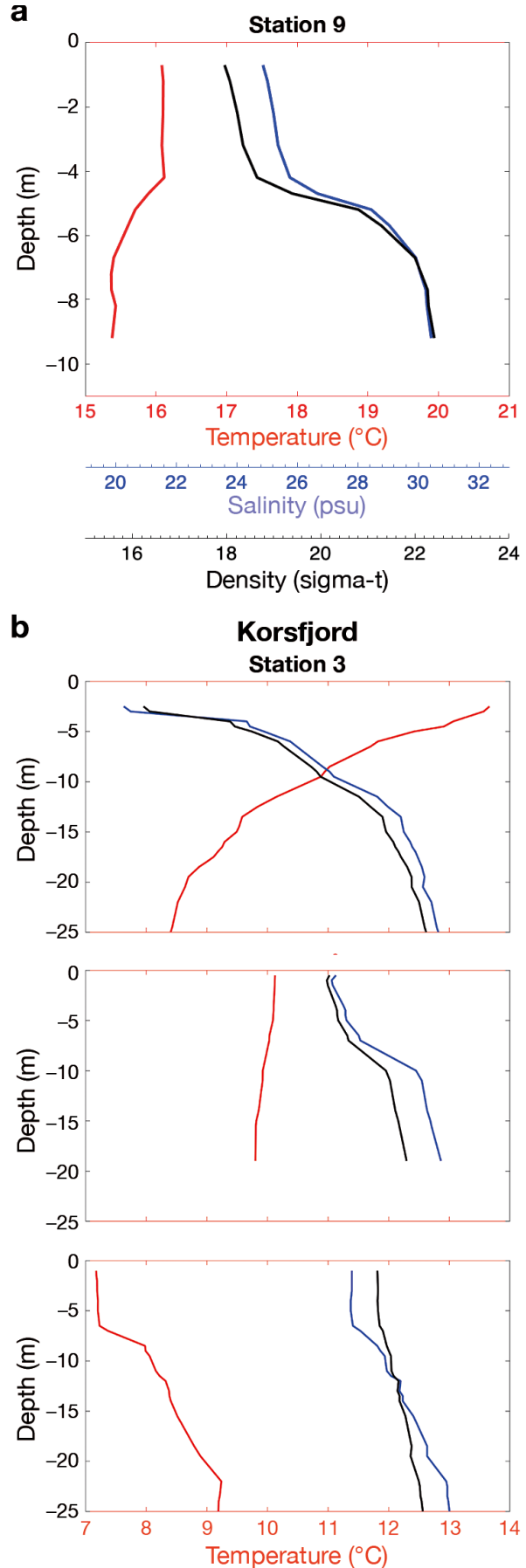

$\begin{array}{lllllllll}30 & 30.5 & 31 & 31.5 & 32 & 32.5 & 33 & 33.5 & 34\end{array}$ Salinity (psu)

$\begin{array}{cccccc}22 & 23 & 24 & 25 & 26 & 27 \\ & & \text { Density (sigma-t) } & & \end{array}$
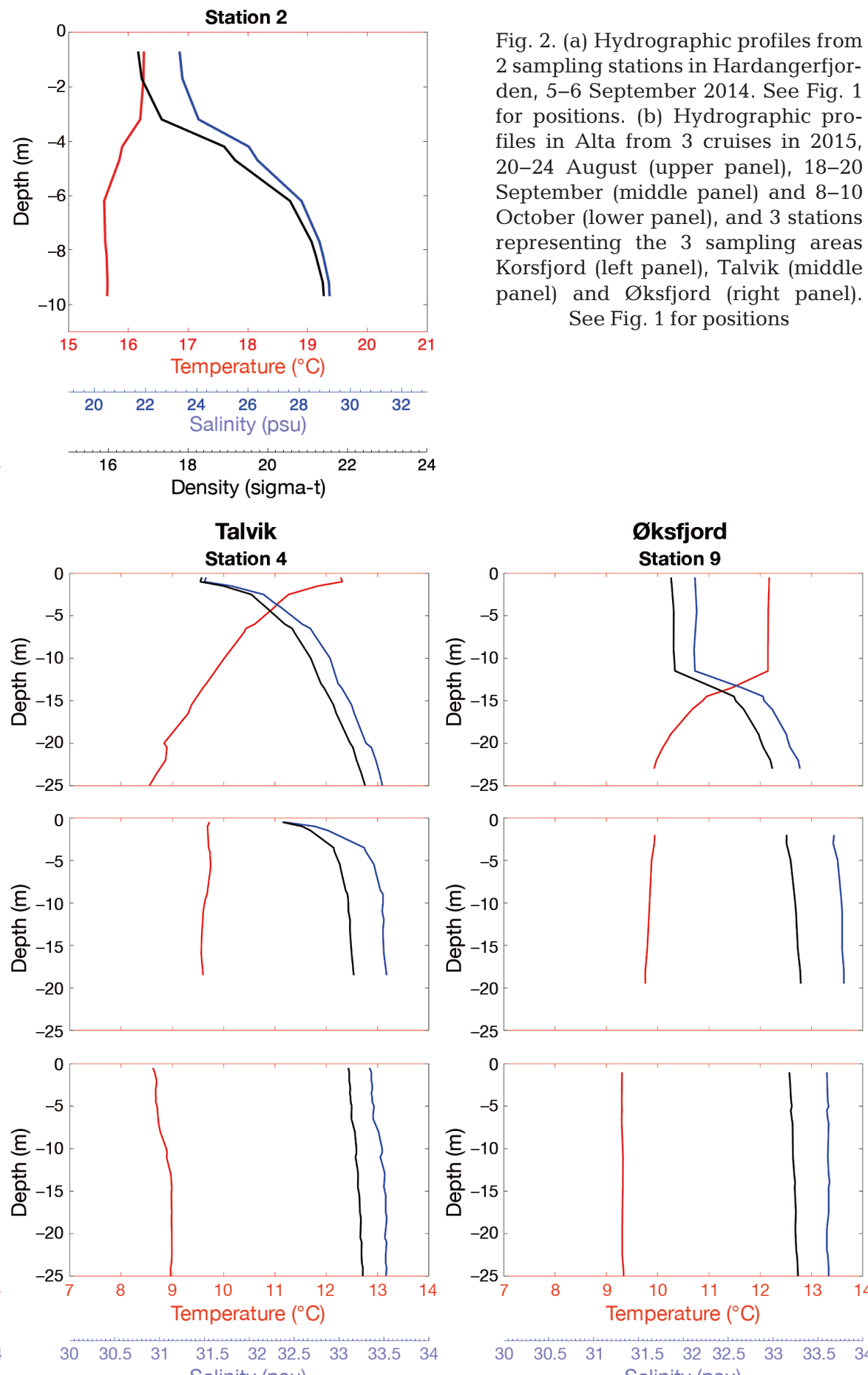

Salinity (psu)

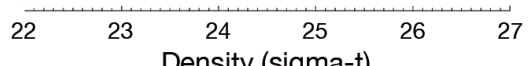

Fig. 2. (a) Hydrographic profiles from 2 sampling stations in Hardangerfjorden, 5-6 September 2014. See Fig. 1 for positions. (b) Hydrographic profiles in Alta from 3 cruises in 2015, 20-24 August (upper panel), 18-20 September (middle panel) and 8-10 October (lower panel), and 3 stations representing the 3 sampling areas Korsfjord (left panel), Talvik (middle panel) and Øksfjord (right panel). See Fig. 1 for positions
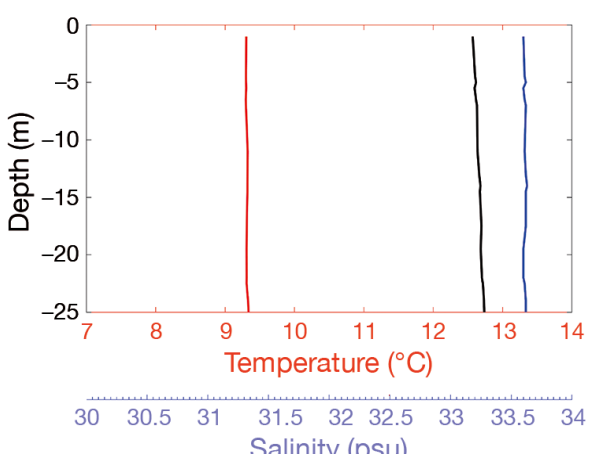
$\begin{array}{ccccccc}22 & 23 & 24 & 25 & 26 & 27 \\ & & \text { Density (sigma-t) }\end{array}$
2018, Skarðhamar et al. 2018) to simulate how the lice abundance varied in time and space. The model system combines the hydrodynamic ocean model ROMS (Regional Ocean Modeling System, (Shchepetkin \& McWilliams 2005, Haidvogel et al. 2008) and the particle-tracking model LADIM (Lagrangian
Advection and Diffusion Model) for salmon lice advection and growth (Ådlandsvik \& Sundby 1994, Ådlandsvik 2018). LADIM includes temperaturedependent growth and development of the lice, mortality and vertical migration (Stien et al. 2005, Johnsen et al. 2014, Samsing et al. 2016). The number of 
lice nauplii released from each salmon farm was calculated based on the lice numbers and fish biomass reported to the authorities. In LADIM, 5 particles were released hourly from every farm location throughout the simulation period, and each particle represents $1 / 5$ of the total nauplii number calculated for each release. See Myksvoll et al. (2018) and Skarðhamar et al. (2018) for details.

In the present work, we used the fine-scale model setup for Altafjorden described in Skarðhamar et al. (2018), covering the coast and fjords between $21.4^{\circ}$ and $26.0^{\circ} \mathrm{E}$, with grid cells of $160 \times 160 \mathrm{~m}$. Boundary conditions of currents, temperature, salinity and sea level were obtained from the operational runs of NorKyst800 (Albretsen et al. 2011) for the time period 10 July to 28 October 2015, available from the Norwegian Meteorological Institute at https://thredds. met.no. For Hardangerfjorden, we applied the operational model setup described in Myksvoll et al. (2018) for the time period 1 August to 30 September 2014 and grid cells $800 \times 800 \mathrm{~m}$. The simulation periods cover the field work periods.

\section{RESULTS}

\subsection{Hydrography}

The CTD measurements from the cruise in Hardanger in September 2014 showed stratified water masses, with a 3 to $4 \mathrm{~m}$ thick surface layer of temperature 15 to $16.5^{\circ} \mathrm{C}$ and salinity 27 to 28 at all stations (represented by Stn 9 in Fig. 2a) except Stn 2, where the surface layer salinity was 24 . Below the surface layer, the temperature decreased to $\sim 15.5^{\circ} \mathrm{C}$ at $10 \mathrm{~m}$ depth at all stations, and the salinity increased to 29-31.

The hydrographic conditions in Alta in 2015 changed between the 3 cruises and sampling areas (Fig. 2b). In Korsfjord and Talvik (Fig. 2b, left and middle panels), the water masses were stratified in August and September, with the pycnocline depth varying between 3 and $12 \mathrm{~m}$ between stations and with weak or no stratification in October. In Øksfjord (Fig. 2b, right panels), a pronounced pycnocline was evident at $12 \mathrm{~m}$ depth in August, below a vertically mixed upper layer, while the profiles showed homogeneous water masses in September and October. The surface layer temperature decreased at all stations from between 12 and $14^{\circ} \mathrm{C}$ in August to ca. $10^{\circ} \mathrm{C}$ in September and between 7.1 and $9.2^{\circ} \mathrm{C}$ in October. For all 3 cruises in Altafjorden, the surface salinity range was 30 to 33.7 .
Salmon lice are known to avoid salinity lower than 20 (Stien et al. 2005). Since we did not measure salinity lower than 24 in Hardangerfjorden and 30 in Altafjorden, we do not expect freshwater avoidance to be of importance here.

\subsection{Salmon lice samples}

In total, 105 samples were collected and analysed for salmon lice: 31 in Hardangerfjorden and 74 in Altafjorden (Table 1); 139 lice copepodid individuals were identified from the laboratory analysis: 16 from the Hardangerfjorden samples and 123 from Altafjorden.

In Hardangerfjorden, lice were found at 6 of 8 stations and 7 of 31 samples, and the concentrations of lice ranged between 0 and 30 ind. $\mathrm{m}^{-3}$ (Table 2), with mean concentration $0.7 \pm 8.8$ ind. $\mathrm{m}^{-3}$. With the Go-Flo-bottles, 1 to 3 lice were present in 3 samples from $3 \mathrm{~m}$ depth, or 10 to 30 ind. $\mathrm{m}^{-3}$, and none in the samples from 5 and $10 \mathrm{~m}$. The vertical net hauls (WP2, 0-10 m) resulted in 1-3 lice per haul at 4 stations, giving lice concentrations of 0.4 to 1.2 ind. $\mathrm{m}^{-3}$. By assuming that lice were present only above $5 \mathrm{~m}$ depth, based on the Go-Flo-results, the WP2-based concentrations can be doubled: 0.8 to 2.4 ind. $\mathrm{m}^{-3}$.

On the 3 cruises in Altafjorden in 2015, lice were found at 8 of 9 stations in both August (19 out of 36 samples) and September (14 out of 18 samples) but at only 1 station (a single louse in 1 sample) in October (Table 2). The number of lice in the samples varied between the 3 parts of the fjord. The Talvik stations had the lowest concentrations of lice on all cruises, ranging from 0 to 0.8 ind $\mathrm{m}^{-3}$ in August and 0 to 2.0 ind. $\mathrm{m}^{-3}$ in September and none in October. In Korsfjorden and Øksfjorden, relatively high concentrations were found in August and September (range 0-13 ind $\mathrm{m}^{-3}$ ) and very low concentrations in October, when only a single louse was found in 1 of the samples from Korsfjorden (Table 2).

The sampling efficiency of the different types of gear is here defined as the mean number of sampled lice copepodids per cubic meter filtered water (see Table 1). This estimate facilitated comparison of the different approaches used on the cruises in Hardanger in September 2014 and in Alta in August 2015. On the cruises in September and October 2015 in Alta, only 1 method was used (pump) due to logistical priorities. For each gear, the number of collected lice and its associated sampling volume were pooled across all stations in each cruise to estimate the sampling efficiency. 
Table 2. Sampled concentrations of salmon lice copepodids (ind. $\mathrm{m}^{-3}$ ) in (a) Hardangerfjorden and (b) Altafjorden (no lice sampling at Stns 4, 8 and 10 in Hardanger)

\begin{tabular}{|c|c|c|c|c|c|c|c|c|c|}
\hline (a) & Stn 1 & Stn 2 & Stn 3 & Stn 5 & Stn 6 & Stn 7 & \multicolumn{2}{|c|}{ Stn 9} & Stn 11 \\
\hline \multicolumn{10}{|l|}{ 4-6 Sep 2014} \\
\hline Go-Flo 3 m & 0.0 & 30.0 & 0.0 & 0.0 & 0.0 & 10.0 & \multicolumn{2}{|c|}{20.0} & 0.0 \\
\hline Go-Flo 5 m & 0.0 & 0.0 & 0.0 & 0.0 & 0.0 & 0.0 & \multicolumn{2}{|c|}{0.0} & 0.0 \\
\hline Go-Flo 10 m & 0.0 & 0.0 & 0.0 & 0.0 & 0.0 & 0.0 & \multicolumn{2}{|c|}{0.0} & 0.0 \\
\hline WP2 horizontal & 0.0 & 1.0 & 0.0 & 0.0 & 0.0 & 0.0 & \multicolumn{2}{|c|}{0.0} & 0.0 \\
\hline WP2 vertical & 1.2 & 0.0 & 0.8 & 1.2 & 0.0 & 0.0 & \multicolumn{2}{|c|}{0.4} & 0.0 \\
\hline \multirow[t]{2}{*}{ (b) } & \multicolumn{3}{|c|}{ Korsfjord } & \multicolumn{2}{|c|}{ - Talvik } & \multicolumn{4}{|c|}{ - Øksfjord } \\
\hline & Stn 1 & Stn 2 & Stn 3 & Stn 4 & Stn 5 & Stn 6 & $\operatorname{Stn} 7$ & Stn 8 & $\operatorname{Stn} 9$ \\
\hline \multicolumn{10}{|l|}{ 22-24 Aug 2015} \\
\hline Go-Flo 3 m & 0.00 & 6.67 & 6.67 & 0.00 & 0.00 & 0.00 & 0.00 & 0.00 & 6.67 \\
\hline Pump 1 m & 0.00 & 0.00 & 2.00 & 0.00 & 0.00 & 2.00 & 6.00 & 1.00 & 0.00 \\
\hline Pump 3 m & 1.00 & 1.00 & 0.00 & 0.00 & 0.00 & 1.00 & 5.00 & 0.00 & 2.00 \\
\hline WP2 0-10 m & 1.20 & 1.60 & 1.60 & 0.80 & 0.00 & 12.80 & 0.00 & 0.80 & 1.20 \\
\hline \multicolumn{10}{|l|}{ 18-20 Sep 2015} \\
\hline Pump $1 \mathrm{~m}$ & 1.00 & 3.00 & 8.00 & 0.00 & 2.00 & 2.00 & 0.00 & 5.00 & 3.00 \\
\hline Pump 3 m & 0.00 & 2.00 & 8.00 & 0.00 & 1.00 & 1.00 & 1.00 & 2.00 & 9.00 \\
\hline \multicolumn{10}{|l|}{ 8-10 Oct 2015} \\
\hline Pump 1 m & 0.00 & 0.00 & 0.00 & 0.00 & 0.00 & 0.00 & 0.00 & 0.00 & 0.00 \\
\hline Pump 3 m & 0.00 & 0.00 & 1.00 & 0.00 & 0.00 & 0.00 & 0.00 & 0.00 & 0.00 \\
\hline
\end{tabular}

The horizontal net haul, using a WP2 net, is the most frequently reported method to obtain salmon lice concentrations and distribution (Costelloe et al. 1998, Penston et al. 2004, 2011, Penston \& Davies 2009, á Norði et al. 2015). On our cruise in Hardangerfjorden, only a single louse was found in 1 of 5 horizontal tows (sampling efficiency of 0.01 ind. $\mathrm{m}^{-3}$ filtered water). We therefore considered this method to be inefficient, and we did not use horizontal tows on the following cruises. Based on the sampling in Hardangerfjorden, the Go-Flo samples from $3 \mathrm{~m}$ depth gave a sampling efficiency of 7.5 ind. $\mathrm{m}^{-3}$, while no lice were found in the samples from 5 and $10 \mathrm{~m}$. The sampling efficiency of the vertical net hauls in Hardangerfjorden was 0.45 ind. $\mathrm{m}^{-3}$.

On the cruise in Altafjorden in August 2015, the sampling efficiency of both the vertical WP2 $(0-10 \mathrm{~m})$ and the Go-Flo bottle $(3 \mathrm{~m})$ was 2.2 ind. $\mathrm{m}^{-3}$, while the pump gave efficiency 1.2 and 1.1 ind. $\mathrm{m}^{-3}$ at 1 and $3 \mathrm{~m}$ depths, respectively. On the following 2 cruises, only the pump was used for sampling, with sampling efficiency 2.7 ind. $\mathrm{m}^{-3}$ on the September cruise and 0.1 ind. $\mathrm{m}^{-3}$ in October.
The total length of all the collected lice copepodids ranged from 400 to $846 \mu \mathrm{m}$ (Fig. 3). The lice sampled in Hardanger had a mean and median total length of 530 and $480 \mu \mathrm{m}$, respectively, while the lice sampled in Altafjorden were larger, with a mean and median total length of 580 and $570 \mu \mathrm{m}$, respectively.

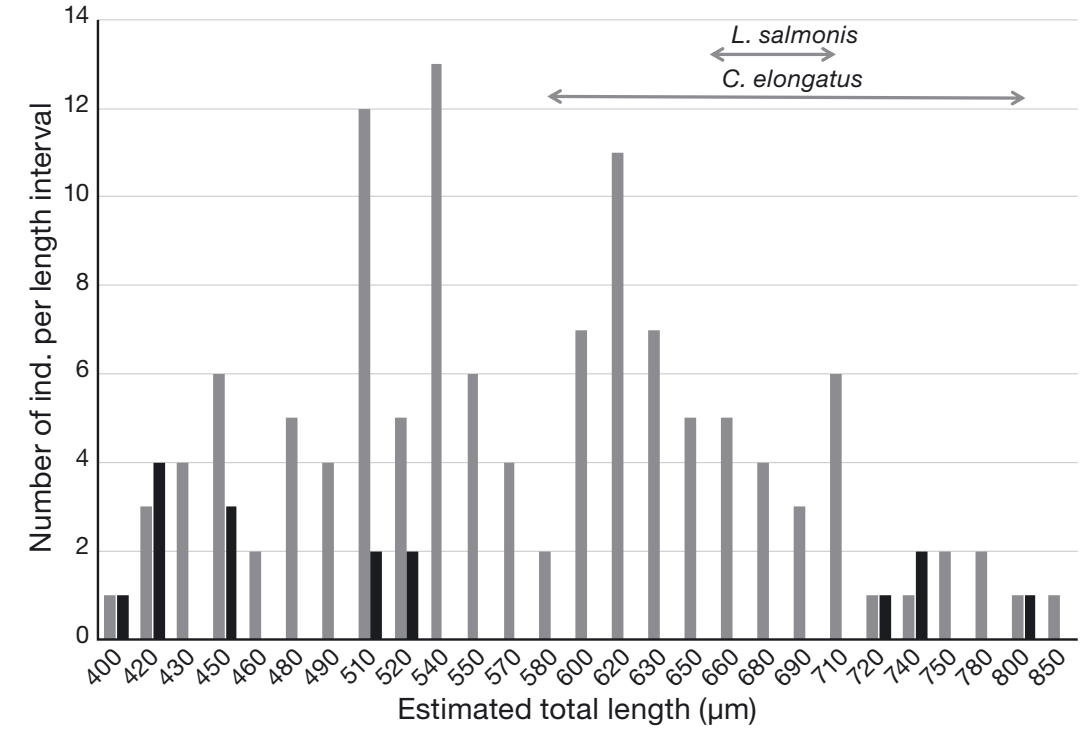

Fig. 3. Size distribution given as total body length measured on pelagic sea lice copepodids $(n=123)$ from Altafjorden in 2015 (gray bars) and Hardangerfjorden in 2014 (black bars). For comparison, the published ranges of total length scales, 580 to $810 \mu \mathrm{m}$ for Caligus elongatus (Piasecki 1996) and 658 to $709 \mu \mathrm{m}$ for Lepeophtheirus salmonis (Schram 1993), are shown with arrows 

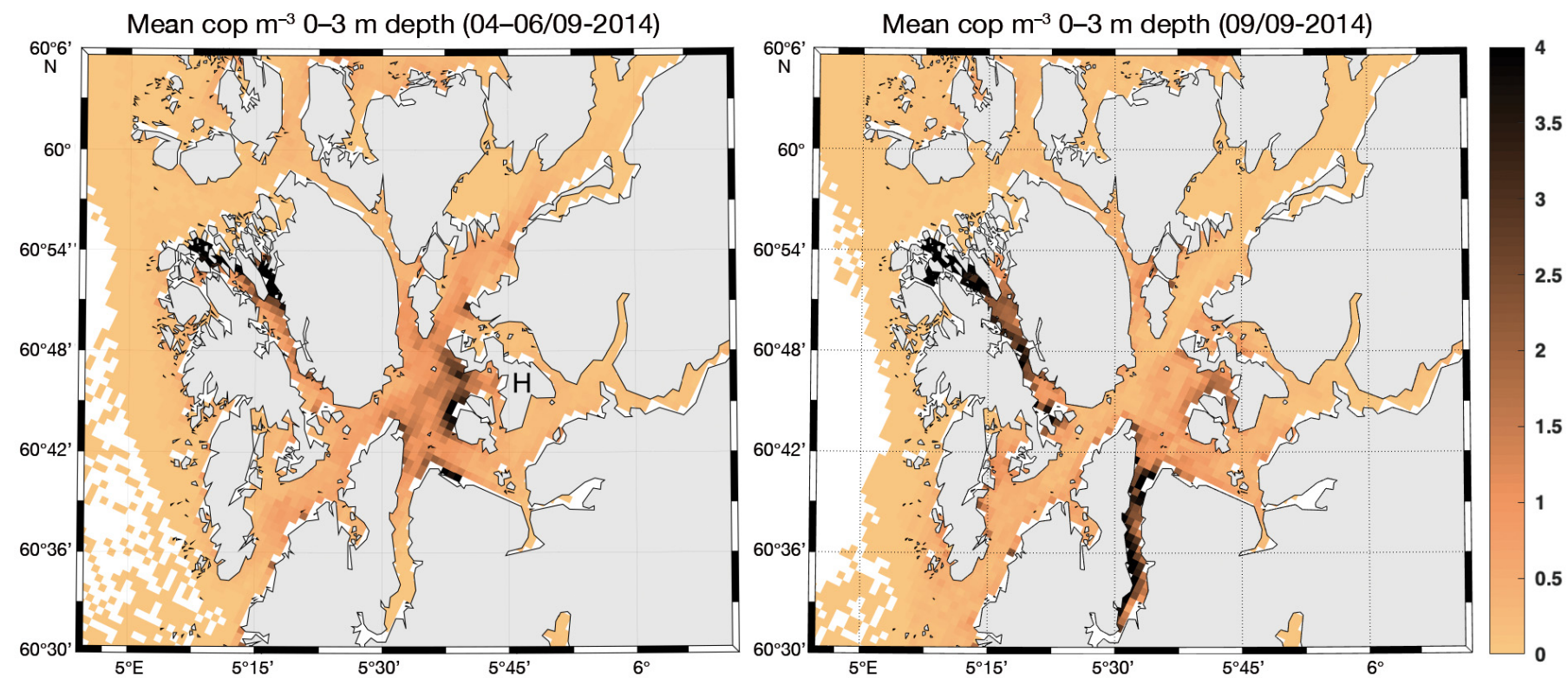

Fig. 4. Modelled abundance of salmon lice copepodids in Hardangerfjorden: mean concentrations (ind. $\mathrm{m}^{-3}$ ) of lice copepodids (cop) per grid cell (area $800 \times 800 \mathrm{~m}^{2}$ ) at 0 to $3 \mathrm{~m}$ depth averaged over $3 \mathrm{~d}$ (left panel), corresponding to the cruise of 4-6 September 2014, and 24 h mean 3 d later (right panel), 9 September 2014

\subsection{Modelled lice concentrations}

In Hardanger, the simulations showed a patch of high lice concentration being advected with the currents into the sampling area from the south, resulting in daily mean concentrations up to 5 ind. $\mathrm{m}^{-3}$ south of Halsnøy during the cruise period (Fig. 4, left panel). Three days later, the patch was dissolved (Fig. 4, right panel).
In Altafjorden, the modelled mean lice concentrations (Fig. 5) were typically 1 order of magnitude lower than in Hardanger. The model results showed large spatiotemporal variability of lice abundance and concentrations in Altafjorden (Table 3, Figs. 5 \& $6)$. In the grid cells representing the sampling stations in Talvik, lice copepodids were present 0 to $4 \%$ of the time steps at Stn 4 and not at all at Stn 5. In Korsfjorden (Stns 2 and 3) and the inner part of Øks-

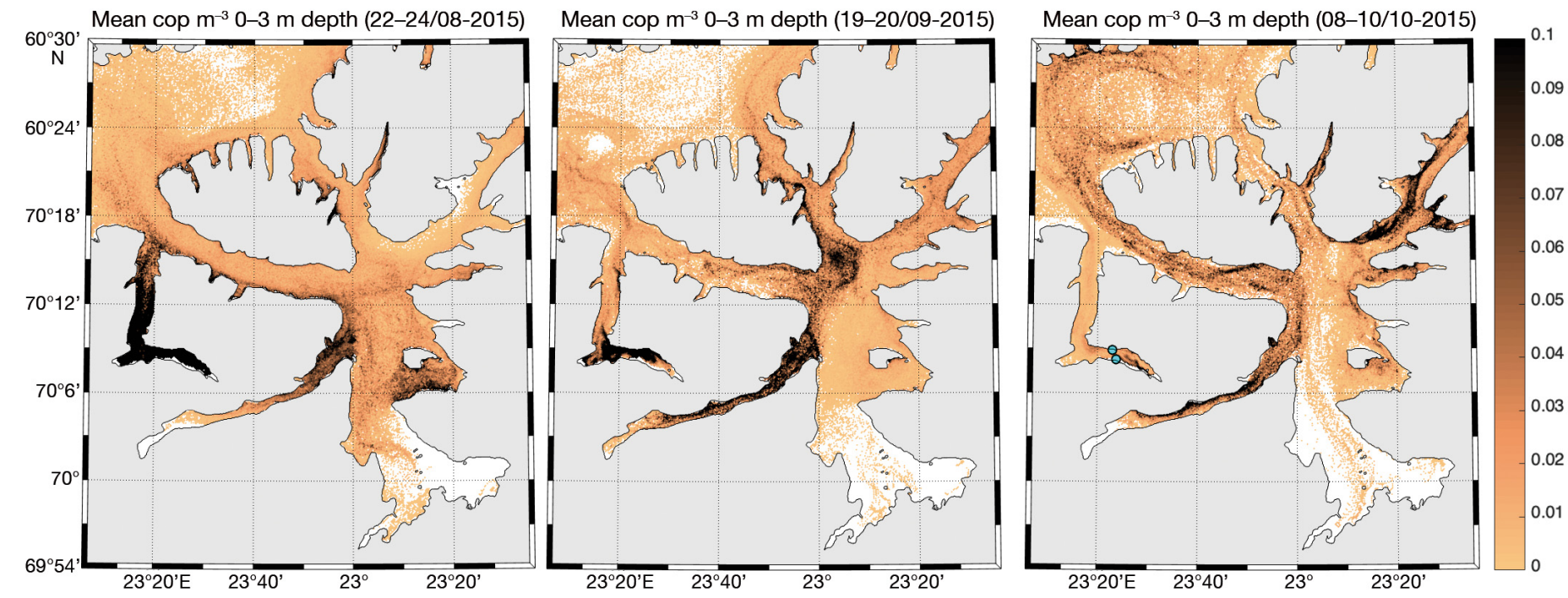

Fig. 5. Modelled abundance of salmon lice copepodids in Altafjorden during the 3 cruise periods. Figures show the mean concentrations (ind. $\mathrm{m}^{-3}$ ) of lice copepodids (cop) per grid cell (area $160 \times 160 \mathrm{~m}^{2}$ ) at 0 to $3 \mathrm{~m}$ depth over 3 periods corresponding to each of the cruise periods. Blue dots in the right panel mark the positions for the time series shown in Fig. 6 
Table 3. Modelled concentrations of salmon lice copepodids (ind. $\mathrm{m}^{-3}$ ) in grid cells representing the sampling stations in Altafjorden in 2015. Mean and maximum concentrations $(n=219)$ are given for the three $73 \mathrm{~h}$ periods representing the cruises, based on hourly model output from 3 depth intervals $\left(0-1,1-2\right.$ and $2-3 \mathrm{~m}$ ). Minimum values at all stations were 0 (ind. $\mathrm{m}^{-3}$ ). The share of time with lice copepodids present in the upper $3 \mathrm{~m}$ at each station is given in percent of time $(\mathrm{n}=73 \mathrm{~h})$

\begin{tabular}{|c|c|c|c|c|c|c|c|c|c|}
\hline & \multicolumn{3}{|c|}{ Korsfjord - } & \multicolumn{2}{|c|}{ Talvik } & \multicolumn{4}{|c|}{ Øksfiord } \\
\hline & Stn 1 & Stn 2 & Stn 3 & Stn 4 & Stn 5 & Stn 6 & $\operatorname{Stn} 7$ & Stn 8 & Stn 9 \\
\hline \multicolumn{10}{|l|}{ 22-24 Aug 2015} \\
\hline Mean & 0.01 & 0.03 & 0.00 & 0.01 & 0.00 & 0.84 & 0.31 & 0.22 & 0.19 \\
\hline $\mathrm{SD}$ & 0.04 & 0.05 & 0.02 & 0.11 & 0.00 & 1.41 & 0.85 & 0.75 & 0.63 \\
\hline Maximum & 0.32 & 0.29 & 0.11 & 1.57 & 0.00 & 7.94 & 5.70 & 3.82 & 4.97 \\
\hline Lice present (\%) & 10 & 78 & 26 & 4 & 0 & 82 & 56 & 36 & 53 \\
\hline \multicolumn{10}{|l|}{ 18-20 Sep 2015} \\
\hline Mean & 0.01 & 0.09 & 0.03 & 0.00 & 0.00 & 7.56 & 0.26 & 0.01 & 0.01 \\
\hline $\mathrm{SD}$ & 0.04 & 0.14 & 0.07 & 0.13 & 0.00 & 6.56 & 0.80 & 0.11 & 0.05 \\
\hline Maximum & 0.24 & 0.81 & 0.43 & 0.19 & 0.00 & 28.76 & 6.05 & 1.51 & 0.50 \\
\hline Lice present (\%) & 16 & 95 & 60 & 1 & 0 & 100 & 36 & 5 & 4 \\
\hline \multicolumn{10}{|l|}{ 8-10 Oct 2015} \\
\hline Mean & 0.01 & 0.57 & 0.45 & 0.00 & 0.00 & 0.04 & 0.03 & 0.01 & 0.01 \\
\hline $\mathrm{SD}$ & 0.05 & 1.02 & 0.95 & 0.00 & 0.00 & 0.07 & 0.10 & 0.02 & 0.02 \\
\hline Maximum & 1.05 & 5.05 & 5.11 & 0.00 & 0.00 & 0.41 & 0.88 & 0.18 & 0.13 \\
\hline Lice present (\%) & 3 & 100 & 63 & 0 & 0 & 52 & 45 & 15 & 18 \\
\hline
\end{tabular}

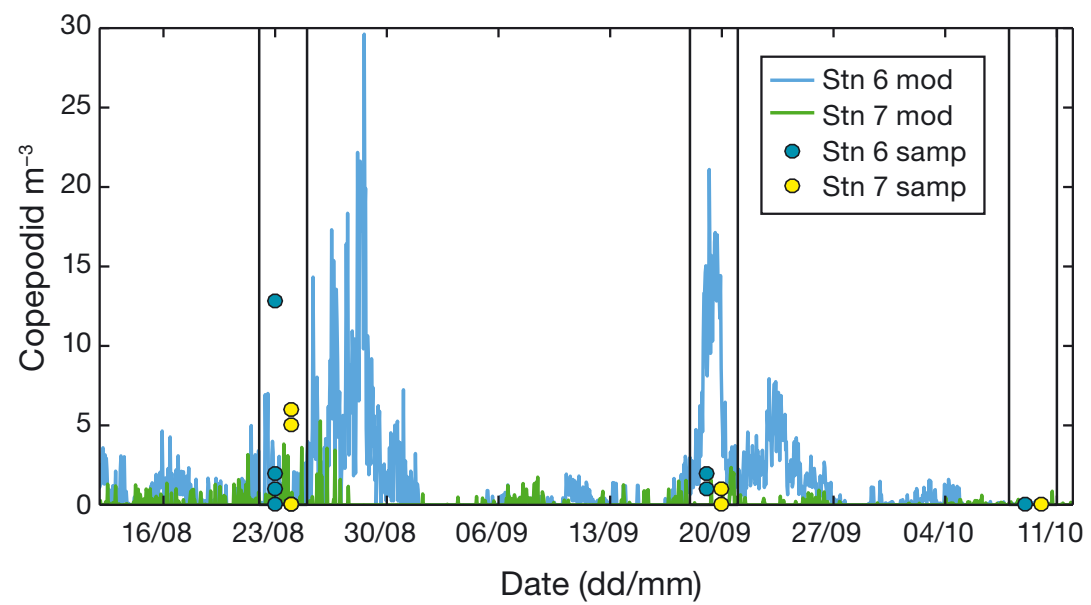

Fig. 6. Modelled (mod) and sampled (samp) lice copepodid concentrations at sampling Stns 6 and 7 in the inner part of Øksfjord (see Fig. 5), August to October 2015. Graphs show model estimates of the number of salmon lice copepodids per cubic meter in grid cells (each of $160 \times 160 \mathrm{~m}^{2}$ ) representing the sampling positions at depth interval 1 to $2 \mathrm{~m}$. Dots represent sampled lice concentrations (Table 2 ) from the 3 cruise periods, marked with vertical lines

Talvik, the modelled concentrations were $<1.6$ ind. $\mathrm{m}^{-3}$ at Stn 4 (note: low presence).

The modelled temporal variability of lice concentrations at the sampling positions was also large during the weeks between the cruise periods (Fig. 6); the highest concentrations appeared in Øksfjord the week after the first cruise period, during the second cruise and the following week, with low concentrations between these periods. In Korsfjorden, the concentrations were low compared to Øksfjord, with increased levels ( 2 ind. $\mathrm{m}^{-3}$ at $2 \mathrm{~m}$ depth) appearing at the end of August (between cruises) and in October during the last cruise period (not shown). In Talvik, the modelled concentrations were low $\left(<0.1\right.$ ind. $\mathrm{m}^{-3}$ at $2 \mathrm{~m}$ depth) the whole modelling period.

The modelled spatial distribution of lice showed that the lice were distributed dif-

fjord (Stns 6 and 7), lice copepodids were present in 26 to $100 \%$ and 36 to $100 \%$, respectively, during the 3 cruise periods (Table 3 ).

The modelled lice concentrations were relatively high in Øksfjord in the first 2 cruise periods, with maximum values of 7.9 ind. $\mathrm{m}^{-3}$ in the first period and 28.8 ind $\mathrm{m}^{-3}$ in the second period. In the third period, the modelled concentrations were low in Øksfjord $\left(<0.9\right.$ ind $\left.\mathrm{m}^{-3}\right)$. The modelled concentrations were low in Korsfjorden in the 2 first periods $(<0.3$ and $<0.8$ ind. $\mathrm{m}^{-3}$ ) and higher in the last period $\left(<5.1\right.$ ind. $\left.\mathrm{m}^{-3}\right)$. In ferently in the fjord system in the 3 cruise periods. In the first period, Øksfjord had the highest concentrations of lice copepodids. The lice field was less dense within Altafjorden, and lice were advected into the Talvik area. In the second period, the most dense lice field was in Langfjord and in the 2 sounds Stjernsund and Rognsund, and in the inner part of Øksfjorden. In the third period, Øksfjorden had low lice concentrations, and no lice copepodids were present in Talvik, while Korsfjorden and all the 3 sounds had higher concentrations of lice (Fig. 5). 


\section{DISCUSSION}

This work presents the first successful field observational data on free-living salmon lice Lepeophtheirus salmonis copepodids in Norwegian fjords. We sampled in areas and periods of expected elevated amounts of lice in the water. We found that salmon lice can be sampled with traditional plankton sampling gear, provided that sufficiently large volumes of water are filtered. However, for obtaining sampling results that represent the actual lice concentrations in an area, a comprehensive survey design is mandatory because the distribution of salmon lice in fjords and coastal waters often is patchy and highly variable in both space and time. Therefore, many samples and large sampling volumes are necessary to obtain representative observational data on planktonic salmon lice that can provide information to assess infestation pressure from lice on wild salmonids and to evaluate modelled lice dispersion.

The modelling results show large variability of lice distribution, in both space and time, caused by the variable currents and eddies that lead to patchiness and filaments (Skarðhamar et al. 2007, Lévy et al. 2018) of elevated lice concentrations, which is in accordance with previous work (Asplin et al. 2014, Johnsen et al. 2014, 2016, Sandvik et al. 2016a, Skarðhamar et al. 2018). Such structures are challenging to sample representatively. To obtain sampling results that represent the actual lice distribution in an area, a comprehensive survey design is therefore mandatory. Our sampling was not designed to capture the full variability of lice abundance. Still, by comparing sampling results with modelled time series of lice concentrations representing the sampling locations, we found that the modelled and observed values of concentrations are within similar ranges.

Sampling of planktonic salmon lice has been considered non-feasible for monitoring the Norwegian coast for salmon lice, due to low success in earlier attempts (Asplin et al. 2011). Our findings show that sampling can be done successfully with traditional gear such as vertical net hauls and by pumping water from specific depths with large water sample bottles (Go-Flo). These methods remain robust during conditions with wind and waves, often a mandatory aspect of coastal monitoring programs. We found GoFlo sampling less convenient and more time consuming than using net hauls and pumping because several repeated samples were needed to obtain sufficiently large volumes of water. Horizontal tows with the WP2 close to the surface, which has been proved successful elsewhere (Costelloe et al. 1998, Penston et al. 2004, 2011, Penston \& Davies 2009, á Norði et al. 2015), were not feasible in our first cruise due to wind and waves and were therefore not repeated on the other cruises. We consider use of horizontal tows to be dependent on sea state (waves) and therefore not reliable as the main method on cruises of fixed dates and duration independent of weather conditions.

The different sampling methods have different qualities with regard to spatiotemporal resolution on horizontal and vertical distribution or integrated vertical concentrations. The vertical net hauls provide integrated concentrations within a depth range, while the Go-Flo bottles and bilge pump sample at specific depths and can be used to assess the vertical distribution. Nelson et al. (2018) compared sampling results from vertical nets hauls and submersible pumps and found no significant difference in mean concentrations of lice larvae, although the variation between samples was high. They based this on vertical net hauls and integrated results of samples pumped from 6 depths at the same station repeated 4 times. On our cruise in Alta in August 2015, we sampled 9 stations and found mean concentrations of 2.2 ind. $\mathrm{m}^{-3}$ sampled with both the vertical net $\left( \pm 4.0\right.$ ind. $\left.\mathrm{m}^{-3} \mathrm{SD}\right)$ and the GoFlo water bottles $\left( \pm 3.3\right.$ ind. $\left.\mathrm{m}^{-3} \mathrm{SD}\right)$ and $1.2 \pm 1.8$ ind. $\mathrm{m}^{-3}$ (mean $\pm \mathrm{SD}$ ) sampled with the pump. This may seem like consistent results; however, the variability was high between stations and methods. With the GoFlo bottles, we caught lice at 3 of 9 stations and only 1 copepodid per sample. Therefore, the Go-Flo-results are burdened with very high uncertainty (e.g. Harris et al. 2000), caused by the low sample volume (150 l, Table 1) combined with vertical patchiness and risk of missing fine-structured distributions. For the vertical net results, Stn 6 contained 32 copepodids, giving a concentration of 12.8 ind. $\mathrm{m}^{-3}$, while the concentrations varied between 0 and 1.6 ind. $\mathrm{m}^{-3}$ at the other stations. The mean concentration of the stations, excluding Stn 6 , was $0.9 \pm 0.6$ ind. $\mathrm{m}^{-3}$. The pump gave a mean concentration of 1.2 ind. $\mathrm{m}^{-3}$ and between 0 and 6 lice per sample. For the pump results, we see that the variations between the 2 depths are small within each station (Table 2). On the 2 cruises in September and October, only the pump was used for sampling, resulting in mean concentrations of $2.7 \pm 2.9$ ind. $\mathrm{m}^{-3}$ in September and $0.1 \pm 0.2$ ind. $\mathrm{m}^{-3}$ in October. The weather was rough during the October cruise, and the absence of lice in the samples may have been caused by winds and waves mixing the lice deeper in the water column. The use of vertical nets would be a more robust method, if lice were present. The 
model simulations (Fig. 5) showed that the currents had transported the lice out of Øksfjord and Talvik, while the modelled lice concentrations increased in Korsfjorden, which was where the single louse was found on the cruise. The modelled high concentrations near the surface can be related to the model parameterisation of the vertical mixing of the particles which will be improved in future simulations.

Based on our results, we consider the 2 methods, vertical net hauls and pumping water from specific depths, feasible for sampling lice. They facilitate large volumes of water to be filtered, and repeated sampling should be carried out to obtain more robust numbers on the actual lice concentrations. In future sampling campaigns, we will therefore increase the pumping volume and repeat the vertical net hauls several times at each station.

Our sampling programme in 2015 was designed to compare sampling methods with different gear and not for proper mapping of the distribution and variability of lice in the fjord system. Such mapping requires a more extensive sampling programme because both the temporal and the spatial variability are large (Asplin et al. 2014, Johnsen et al. 2014, 2016, Sandvik et al. 2016a, Skarðhamar et al. 2018). However, we sampled at 9 stations at 3 widely separated localities and 3 time periods in Alta in 2015. What we can conclude from our results is that higher lice concentrations were present in Korsfjord and Øksfjord, which are both active aquaculture areas, than in Talvik within the protected part of the fjord. However, lice were present also in Talvik, and in September the concentrations found in Talvik were within the lower end of the range of the other 2 localities. This is not surprising since lice from most farm sites in the fjord are likely to be advected with the currents into the protected part of the fjord (Skarðhamar et al. 2018).

The modelling results of lice concentrations at the sampling locations showed large variability in both time and space (Table 3). On the 2 first cruises in Alta (August and September), lice were found at 8 of 9 stations (Table 2). The maximum modelled concentrations at each of these stations and cruise periods were lower than sampled concentrations at 6 of these 8 stations and higher at 2 stations in both periods. Of the 2 stations with no sampled lice, the model estimated no lice at one station and a minor concentration at the other. Our results show that the modelled and sampled abundances varied within similar ranges, but were partly shifted in time. The model overall estimated lower concentrations than observed, with a few exceptions. In the cases where the difference be- tween sampled and modelled abundance was high, the sampled values were generally higher than simulated (Table 3), with 1 exception (Stn 6 in September). Based on this comparison, we state that the model estimates conservative lice concentrations. This holds also if we assume that, for example, $50 \%$ of the sampled lice were Caligus elongatus.

The range of magnitudes of the concentrations estimated from the samples is similar to the modelled range of concentrations; however, the variability may not be accurate in time. For example, the highest concentration was sampled at 1 station in Øksfjord on the August cruise, while the model estimated concentrations of similar magnitude (and higher) at the same position a few days later than the cruise period (Fig. 6). The second cruise period (in September) matched the modelled peak concentrations at the same stations, but these peak values were not reflected in the sampled concentrations, which were of similar magnitude as the modelled concentrations a few days earlier and later. The period of the third cruise, when no lice were sampled in Øksfjorden, matched low lice concentrations modelled in that part of the fjord $\left(<1\right.$ ind. $\left.\mathrm{m}^{-3}\right)$.

The variability of lice concentrations in time and space depends on the variability of the currents transporting them and patchiness and filaments that can cause large differences in concentrations of lice and other plankton over short distances and time (Skarðhamar et al. 2007, Lévy et al. 2018). Such structures and variability are challenging to capture in a sampling survey, requiring a dense sampling programme and resources to analyse a large number of samples in the laboratory. Numerical modelling with sufficient spatial resolution resolves such structures and is therefore an unsurpassed tool for mapping distribution and variability of salmon lice. A comprehensive discussion about the accuracy and variability in the physics and salmon lice densities can be found in Sandvik et al. $(2016 a, b)$ and references therein.

The accuracy of the model results also depends on the quality of the input data on lice: the numbers of lice released to the waters from the aquaculture farms over time. This is based on weekly reports of lice prevalence (no. of lice fish ${ }^{-1}$ ) and monthly reports on biomass (no. of fish) reported by each farm. The farms do not report exact date, only week number and month. We therefore consider the uncertainty of timing of the lice numbers to be about $2 \mathrm{wk}$. This can be one factor affecting the timing of modelled peak concentrations in certain areas. Biomass optimally should also have been reported weekly with exact 
dates. Still, compared to other countries, the Norwegian reporting system provides unique and realistic input data sets of lice larvae released from every fish farm, making us able to model the lice abundance and distribution with the currents relatively realistically. By including exact dates in the reporting system, our modelling results can be even more accurate in the future. In other countries facing challenges with aquaculture and salmon threatening wild salmonid populations, full reporting systems for the aquaculture farms have not yet been established; the management is based on treatment thresholds of lice per fish (varying between countries) and allowed fish biomass, and reported numbers of both lice and fish per farm are not available. Modelling studies are therefore used for connectivity analysis between farms without realistic input data on lice nauplii released from the farms (e.g. Adams et al. 2016, Salama et al. 2016, Cantrell et al. 2018, Kragesteen et al. 2019). By establishing open reporting systems for lice observed on farmed fish, and the number of fish per farm (biomass), the management systems can be improved.

The 2 sea lice species ( $L$. salmonis and C. elongatus) are relatively similar in morphology and overlapping size and therefore hard to distinguish from each other in their larval stages. In northern Norway (Elvik et al. 2016), as well as in northern parts of Iceland (Karbowski et al. 2019), C. elongatus significantly contributes to sea lice abundance both in wild sea trout as well as in sentinel caged salmon smolts. Farmed salmon are also annually challenged with autumn sea lice epizootics, in both Iceland and northern Norway (Karbowski et al. 2019). It is therefore also important to be able to distinguish the 2 species in pelagic monitoring programs, especially from August to November. Schram (2004) recommends using pigmentation characteristics for distinguishing the 2 species from each other morphologically. However, pigment degradation is a challenge due to the use of fixatives for preservation. Formaldehyde is the preferred fixative for crustacean plankton (Harris et al. 2000), but this induces fast decolourisation. Ethanol preserves the pigmentation better, but the pigmentation will fade in ethanol preservation after a week (Schram 2004). The recommended identification prior to fixation, or within a week in ethanolpreserved samples, was not feasible in Altafjorden due to field sampling occurring far from laboratory facilities and the time required for analysis of entire plankton samples to identify the salmon lice copepodids. Formaldehyde was therefore selected for better general preservation. Even though we could not identify the 2 species based on pigmentation characteristics, the frequency of total length distributions in Alta (Fig. 3) indicates at least 2 peaks (510-540 and 600-630 $\mu \mathrm{m}$ ) and therefore 2 potential populations or species, although these lengths are shorter than literature values of total length (Schram 1993, Piasecki 1996). There is possibly a size difference in wild copepodid sea lice (present study) compared to laboratory-reared copepodids used in the cited studies, probably caused by growth at lower temperatures, or length frequency distributions being impacted by size-dependent predation in nature.

Our samples were analysed manually with a microscope in the laboratory. Given the low number of lice in each sample, the whole sample had to be scrutinised; analysis of subsamples, which is a normal procedure for other plankton sampling, could not be used here. Therefore, the analysis was time consuming, and more efficient analysis methods can be beneficial, such as image analysis and environmental DNA and other molecular methods. Investigations of such methods have been conducted in parallel with this study, but although promising, a skilled microscope analyser still is the most accurate and precise method (R. Skern-Mauritzen, Institute of Marine Research, pers. comm., S. Bui unpubl. data). The development of automatic analysis methods is advancing rapidly, so we expect more efficient, but still accurate and precise, analysis methods to be available in the future.

The numbers of lice sampled during our cruises were too low to allow robust statistical analysis, and the uncertainty in concentrations is potentially high (35-100\% according to Harris et al. 2000). However, since no previous direct observational-based information is available on concentrations and distribution of free-living salmon lice copepodids in Norwegian fjords, we consider our results valuable as a first direct quantification (snapshot) of lice concentrations in Norwegian fjords with aquaculture. The mostly higher concentrations found in our samples compared to those in Nelson et al. (2018) and the literature (see references therein) also seem reliable, based on the scale of the Norwegian aquaculture industry and the role of farms as emission sources for lice larvae in the fjords.

\section{CONCLUSIONS}

We have shown that sampling for salmon lice is possible with conventional sampling equipment for zooplankton, provided that sufficiently large water 
volumes (>1000 l) are filtered. Based on our experience, we consider vertical net hauls with WP2 nets to be the most robust sampling method, independent of weather conditions, and time effective and therefore especially suitable for monitoring programmes. Alternatively, pumping large volumes from specific depths into a WP2 net for filtration can also be feasible, especially if vertical distribution is important.

Previous model results have shown a highly variable lice dispersion in time and space (Myksvoll et al. 2012, Asplin et al. 2014, Johnsen et al. 2014, 2016, Skarðhamar et al. 2018), and our observations and modelling results for Hardangerfjorden and Altafjorden support this. Therefore, to develop a field-based monitoring program for free-living lice, the field sampling effort and survey design must be thoroughly considered and extensively conducted to ensure that the expected variability in time and space is covered by the sampling programme. Such monitoring programmes require an extensive sampling programme and manual resources for analysing the samples and will demand large resources if implemented all along the coast. But for targeted studies in selected regions, sampling efforts can be valuable for research, and observational data on planktonic salmon lice concentrations can provide valuable additional information for assessing infestation pressures from sea lice on wild salmonids. Such data can also be valuable for evaluation of model estimates of lice concentrations and to develop a more functional relationship in time and space between modelled concentrations of planktonic lice to the observations of lice attached to salmonid fish. The present work indicates that the model can be considered to estimate conservative concentrations of free-living lice copepodids, within the same order of magnitude as our sampling results of free-living lice. Comparisons between modelled lice abundance and available data on lice infestation on wild-caught sea trout (Myksvoll et al. 2018) as well as sentinel caged salmon smolts (Sandvik et al. 2016a) showed good agreement. Together, these are arguments for further development and use of the hydrodynamic lice model as a primary tool for governmental monitoring and management purposes.

Acknowledgements. This work was funded by the Norwegian Research Council through Regionalt Forskningsfond Fondsregion Nord-Norge, project number 239142, and the research programme MIKON at the Fram Centre in Tromsø, Norway. We thank the captains and crews of the RVs 'Fangst' and 'Hans Brattstrøm' and the Norwegian Coast Guard Vessels 'Farm' and 'Heimdal' for their excellent cooperation and assistance on the cruises.

\section{LITERATURE CITED}

á Norði G, Simonsen K, Danielsen E, Eliasen K and others (2015) Abundance and distribution of planktonic Lepeophtheirus salmonis and Caligus elongatus in a fish farming region in the Faroe Islands. Aquacult Environ Interact 7:15-27

á Norði G, Simonsen K, Patursson Ø (2016) A method of estimating in situ salmon louse nauplii production at fish farms. Aquacult Environ Interact 8:397-405

Aasetre J, Vik J (2013) Framing the environment - Disputes and developments in the management of Norwegian salmon fjords. Ocean Coast Manage 71:203-212

Adams TP, Aleynik D, Black KD (2016) Temporal variability in sea lice population connectivity and implications for regional management protocols. Aquacult Environ Interact 8:585-596

Ådlandsvik B (2018) LADiM documentation, release 1.1.0. https://buildmedia.readthedocs.org/media/pdf/ladim/ master/ladim.pdf

Ådlandsvik B, Sundby S (1994) Modelling the transport of cod larvae from the Lofoten area. ICES Mar Sci Symp 198:379-392

Albretsen J, Sperrevik AK, Staalstrøm A, Sandvik AD, Vikebø FB, Asplin L (2011) NorKyst-800 report no. 1: User manual and technical descriptions. Fisken og havet 2-2011. Institute of Marine Research, Bergen

Anonymous (2015) Forutsigbar og miljømessig bærekraftig vekst i norsk lakse- og ørretoppdrett. Meld. St. 16 (20142015). Ministry of Trade, Industry and Fisheries, Oslo (in Norwegian)

Ashley PJ (2007) Fish welfare: current issues in aquaculture. Appl Anim Behav Sci 104:199-235

Asplin L, Boxaspen KK, Sandvik AD (2011) Modeling the distribution and abundance of planktonic larval stages of Lepeophtheirus salmonis in Norway. In: Jones S, Beamish $\mathrm{R}$ (eds) Salmon lice: an integrated approach to understanding parasite abundance and distribution. WileyBlackwell, Oxford, p 31-50

Asplin L, Johnsen IA, Sandvik AD, Albretsen J, Sundfjord V, Aure J, Boxaspen KK (2014) Dispersion of salmon lice in the Hardangerfjord. Mar Biol Res 10:216-225

* Birkeland K (1996) Consequences of premature return by sea trout (Salmo trutta) infested with the salmon louse (Lepeophtheirus salmonis Krøyer): migration, growth, and mortality. Can J Fish Aquat Sci 53:2808-2813

Cantrell DL, Rees EE, Vanderstichel R, Grant J, Filgueira R, Revie CW (2018) The use of kernel density estimation with a bio-physical model provides a method to quantify connectivity among salmon farms: spatial planning and management with epidemiological relevance. Front Vet Sci 5:269

Costello MJ (2009) How sea lice from salmon farms may cause wild salmonid declines in Europe and North America and be a threat to fishes elsewhere. Proc R Soc B 276 : 3385-3394

Costelloe M, Costelloe J, Coghlan N, O'Donohoe G, O'Connor B (1998) Distribution of the larval stages of Lepeophtheirus salmonis in three bays on the west coast of Ireland. ICES J Mar Sci 55:181-187

Danielsen E (2013) Identification of the free swimm ing larval stages of Caligus elongatus and Lepeophtheirus salmonis. Fiskaaling rit 2013-5, Technical Report. Fiskaaling, Faroe Islands

*Eilertsen HC, Skarðhamar J (2006) Temperatures of north Norwegian fjords and coastal waters: variability, signifi- 
cance of local processes and air-sea heat exchange. Estuar Coast Shelf Sci 67:530-538

Elvik KMS, Nilsen R, Serra-Llinnares RM, Halttunen E, Bjørn PA, Karlsen Ø, Kvamme BO (2016) Sampling methods for monitoring sea lice on wild sea trout. Poster presented at 11 th Int Sea Lice Conf, Westport, Ireland, 26-28 September 2016

Forseth T, Barlaup BT, Finstad B, Fiske P and others (2017) The major threats to Atlantic salmon in Norway. ICES J Mar Sci 74:1496-1513

Grefsrud ES, Glover K, Grøsvik BE, Husa V and others (2018) Risikorapport norsk fiskeoppdrett 2018. Fisken og havet, særnr. 1-2018. Institute of Marine Research, Bergen (in Norwegian)

*Haidvogel DB, Arango H, Budgell WP, Cornuelle BD and others (2008) Ocean forecasting in terrain-following coordinates: formulation and skill assessment of the Regional Ocean Modeling System. J Comput Phys 227: 3595-3624

Halvorsen E, Tande KS, Høisæter T (1999) Physical and biological factors influencing the seasonal variation in disatributrion of zooplanton across the shelf at Nordvestbaskem, northern Norway, 1994. Sarsia 84: 279-292

Harris R, Wiebe P, Lenz J, Skjoldal HR, Huntley M (eds) (2000) ICES zooplankton methodology manual. Academic Press, San Diego, CA

Johnsen IA, Fiksen Ø, Sandvik AD, Asplin L (2014) Vertical salmon lice behaviour as a response to environmental conditions and its influence on regional dispersion in a fjord system. Aquacult Environ Interact 5:127-141

Johnsen IA, Asplin LC, Sandvik AD, Serra-Llinares RM (2016) Salmon lice dispersion in a northern Norwegian fjord system and the impact of vertical movements. Aquacult Environ Interact 8:99-116

Karbowski CM, Finstad B, Karbowski N, Hedger RD (2019) Sea lice in Iceland: assessing the status and current implications for aquaculture and wild salmonids. Aquacult Environ Interact 11:149-160

Kragesteen TJ, Simonsen K, Visser AW, Andersen KH (2019) Optimal salmon lice treatment threshold and tragedy of the commons in salmon farm networks. Aquaculture 512: 734329

Lévy M, Franks PJS, Smith KS (2018) The role of submesoscale currents in structuring marine ecosystems. Nat Commun 9:4758

Mankettikkara R (2013) Hydrophysical characteristics of the northern Norwegian coast and fjords. PhD thesis, University of Tromsø

Myksvoll MS, Sandvik AD, Skarðhamar J, Sundby S (2012) Importance of high resolution wind forcing on eddy activity and particle dispersion in a Norwegian fjord. Estuar Coast Shelf Sci 113:293-304

* Myksvoll MS, Sandvik AD, Albretsen J, Asplin L and others (2018) Evaluation of a national operational salmon lice monitoring system - from physics to fish. PLOS ONE 13: e0201338

Nelson EJ, Robinson SMC, Feindel N, Sterling A, Byrne A, Pee Ang K (2018) Horizontal and vertical distribution of sea lice larvae (Lepeophtheirus salmonis) in and around salmon farms in the Bay of Fundy, Canada. J Fish Dis 41: 885-899

Penston MJ, Davies IM (2009) An assessment of salmon farms and wild salmonids as sources of Lepeophtheirus salmonis (Krøyer) copepodids in the water column in Loch Torridon, Scotland. J Fish Dis 32:75-88

Penston MJ, McKibben MA, Hay DW, Gillibrand PA (2004) Observations on open-water densities of sea lice larvae in Loch Shieldaig, western Scotland. Aquacult Res 35: 793-805

Fenston MJ, McBeath AJA, Millar CP (2011) Densities of planktonic Lepeophtheirus salmonis before and after an Atlantic salmon farm relocation. Aquacult Environ Interact 1:225-232

Petterson LE (2008) Beregning av totalavløp til Hardangerfjorden. Oppdragsrapport A nr 9 2008. Norges vassdragsog energidirektorat (NVE), Oslo (in Norwegian)

*Piasecki W (1996) The developmental stages of Caligus elongatus von Nordmann, 1832 (Copepoda: Caligidae). Can J Zool 74:1459-1478

Røhr PC, Larsen CK, Øydvin EK (2003) Flomsonekart, Delprosjekt Alta-Eiby. Rapport nr 10/2003. Norges vassdrags- og energidirektorat (NVE), Oslo

Salama NKG, Murray AG, Rabe B (2016) Simulated environmental transport distances of Lepeophtheirus salmonis in Loch Linnhe, Scotland, for informing aquaculture area management structures. J Fish Dis 39:419-428

Salama NKG, Dale AC, Ivanov VV, Cook PF, Pert CC, Collins CM, Rabe B (2018) Using biological-physical modelling for informing sea lice dispersal in Loch Linnhe, Scotland. J Fish Dis 41:901-919

Samsing F, Oppedal F, Dalvin S, Johnsen I, Vågseth T, Dempster T (2016) Salmon lice (Lepeophtheirus salmonis) development times, body size, and reproductive outputs follow universal models of temperature dependence. Can J Fish Aquat Sci 73:1841-1851

Sandvik AD, Bjørn PA, Ådlandsvik B, Asplin L and others (2016a) Toward a model-based prediction system for salmon lice infestation pressure. Aquacult Environ Interact 8:527-542

Sandvik AD, Skagseth O, Skogen MD (2016b) Model validation: issues regarding comparisons of point measurements and high-resolution modeling results. Ocean Model 106:68-73

Schram TA (1993) Supplementary descriptions of the developmental stages of Lepeophtheirus salmonis (Krøyer, 1837) (Copepoda: Caligidae). In: Boxshall GA, Defaye D (eds) Pathogens of wild and farmed fish: sea lice. Ellis Horwood, Chichester, p 30-47

* Schram TA (2004) Practical identification of pelagic sea lice larvae. J Mar Biol Assoc UK 84:103-110

Serra-Llinares RM, Freitas C, Nilsen R, Elvik KMS and others (2018) Towards direct evidence of the effects of salmon lice (Lepeophtheirus salmonis Krøyer) on sea trout (Salmo trutta L.) in their natural habitat: proof of concept for a new combination of methods. Environ Biol Fishes 101:1677-1692

* Shchepetkin AF, McWilliams JC (2005) The regional oceanic modeling system (ROMS): a split-explicit, free-surface, topography-following-coordinate oceanic model. Ocean Model 9:347-404

* Skarðhamar J, Slagstad D, Edvardsen A (2007) Plankton distributions related to hydrography and circulation dynamics on a narrow continental shelf off northern Norway. Estuar Coast Shelf Sci 75:381-392

Skarðhamar J, Albretsen J, Sandvik AD, Lien VS and others (2018) Modelled salmon lice dispersion and infestation patterns in a sub-arctic fjord. ICES J Mar Sci 75: 1733-1747 
Skjoldal HR, Wiebe PH, Postel L, Knutsen T, Kaartvedt S, Sameoto DD (2013) Intercomparison of zooplankton (net) sampling systems: results from the ICES/GLOBEC seagoing workshop. Prog Oceanogr 108:1-42

Sønvisen SA (2003) Integrated coastal zone management (ICZM). The allocation of space in Norwegian aquaculture - from local lottery to central planning? MSc thesis, University of Tromsø

Stien A, Bjørn PA, Heuch PA, Elston DA (2005) Population dynamics of salmon lice Lepeophtheirus salmonis on Atlantic salmon and sea trout. Mar Ecol Prog Ser 290:263-275

Editorial responsibility: Kate S. Hutson, Nelson, New Zealand
Taranger GL, Karlsen Ø, Bannister RJ, Glover KA and others (2015) Risk assessment of the environmental impact of Norwegian Atlantic salmon farming. ICES J Mar Sci 72: 997-1021

Thorstad EB, Todd CD, Uglem I, Bjørn PA and others (2015) Effects of Atlantic salmon lice Lepeophtheirus salmonis on wild sea trout Salmo trutta-a literature review. Aquacult Environ Interact 7:91-113

*Vollset KW, Dohoo I, Karlsen Ø, Halttunen E and others (2018) Disentangling the role of sea lice on the marine survival of Atlantic salmon. ICES J Mar Sci 75:50-60

Submitted: May 22, 2019; Accepted: October 18, 2019

Proofs received from author(s): December 10, 2019 